\title{
Dampak Pandemi Covid-19 terhadap Minat Beli Masyarakat di Kecamatan Lambuya Kabupaten Konawe Provinsi Sulawesi Tenggara
}

\author{
${ }^{1}$ Muhamad Pariama dan ${ }^{2}$ Takwim \\ ${ }^{1}$ Universitas Lakidende Unaaha \\ ${ }^{2}$ Universitas Lakidende Unaaha \\ Correspondence email: pariamapariama8@gmail.com
}

\begin{abstract}
Abstrak: Work From Home atau WFH dan social distancing membuat pergerakan masyarakat dalam kehidupan mandek karena pada Work From Home atau WFH orang tidak bisa keluar rumah dan dengan social distancing, masyarakat dilarang keras melakukan aktivitas yang berkumpul atau berkelompok. Namun, mereka tetap harus memenuhi kebutuhan sehari-hari. Hal ini mempengaruhi kehidupan masyarakat, termasuk sektor ekonomi. Banyak toko dan tempat jual beli tutup sehingga masyarakat kesulitan memenuhi kebutuhan sehari-hari. Larangan keluar rumah membuat ruang gerak masyarakat semakin sempit. Larangan keluar rumah membuat ruang gerak masyarakat semakin sempit. Padahal justru di saat seperti inilah kebutuhan hidup semakin meningkat sehingga mempengaruhi niat beli masyarakat. Situasi tersebut telah mengubah persepsi masyarakat ke tingkat psikologis baru dalam menentukan keputusan mereka untuk melakukan pembelian kebutuhan pokok. Dalam situasi normal, produk, harga, dan tempat secara langsung dapat mempengaruhi keputusan pembelian, tetapi dalam keadaan darurat akan menyebabkan hasil lain seperti perubahan perilaku konsumen dan perubahan pola pengeluaran selama pandemi COVID-19. Penelitian ini bertujuan untuk mengetahui dampak dari pandemi Covid-19. 19 Tentang Minat Beli Masyarakat Di Kecamatan Lambuya Kabupaten Konawe Provinsi Sulawesi Tenggara. Pengamatan awal menunjukkan adanya perubahan perilaku konsumen dan perubahan pola belanja selama pandemi COVID-19 terhadap minat beli masyarakat. Indikasi ini terlihat karena minat beli barang kebutuhan pokok menurun, karena masyarakat dihimbau oleh pemerintah untuk melakukan social distancing guna memutus mata rantai penyebaran virus COVID-19. Dalam penelitian ini jumlah sampel yang digunakan adalah 150 responden. Untuk menganalisis data survei, menginterpretasikan hasil penelitian, digunakan teknik analisis regresi linier berganda, untuk mengetahui seberapa besar pengaruh antara perubahan perilaku konsumen dan perubahan pola pengeluaran terhadap minat beli masyarakat. Teknik pengumpulan data dilakukan melalui kuesioner. Skala pengukuran menggunakan skala Likert. Sumber data yang digunakan adalah data primer dan data sekunder.
\end{abstract}

Kata kunci: Pandemi Covid-19, Minat Beli, Masyarakat

Abstract: Work From Home or WFH and social distancing make people's movements in life stagnate because at Work From Home or WFH people cannot leave the house and with social distancing, people are strictly prohibited from doing activities that are gathered or in groups. However, they still have to fulfill their daily needs. This affects people's lives, including the economic sector. Many shops and buying and selling places are closed so that people find it difficult to meet their daily needs. The prohibition to leave the house makes the community's space to move narrower. The prohibition to leave the house makes the community's space to move narrower. In fact, it is precisely at times like this that the needs of life are increasing so that it affects people's buying intentions. The situation has changed people's perceptions into a new psychological level in determining their decision to make purchases of basic necessities. In a normal situation, products, prices and places can directly influence buying decisions, but in an emergency, it will lead to other results such as changes in consumer behavior and changes in spending patterns during the COVID-19 pandemic. This study aims to determine the impact of the Covid-19 pandemic. 19 on the Buying Interest of the Community in the District of Lambuya, Konawe Regency, Southeast Sulawesi Province. Initial observations show that there are changes in consumer behavior and changes in spending patterns during the COVID-19 pandemic on people's buying interest. This indication can be seen because the interest in buying necessities has decreased, because the public is being urged by the government to practice social distancing to break the chain of the spread of the COVID-19 virus. In this study, the number of samples used was 150 respondents. To analyze the survey data, interpret the research results, multiple linear regression analysis techniques are used, to find out how much influence between changes in consumer behavior and changes in 
Muhammad Pariama dan Takwim, Dampak Pandemi Covid-19 terhadap Minat Beli Masyarakat di Kecamatan Lambuya Kabupaten Konawe Provinsi Sulawesi Tenggara

spending patterns on people's buying interest. Data collection techniques were carried out through questionnaires. The measurement scale uses a Likert scale. Sources of data used are primary data and secondary data.

Keywords: Covid-19 Pandemic, Buying Interest, Society

\section{PENDAHULUAN}

Indonesia sebagai salah satu negara yang juga mengalami pandemi Covid-19 sejak awal Maret 2020 merasakan dampak yang besar di semua sektor kehidupan terutama sektor ekonomi. Virus Covid-19 yang begitu mematikan, yang menyerang saluran pernafasan dapat mudah menular kepada siapa saja. Hal ini terutama cepat terjadi kepada seseorang yang daya tahan tubuhnya lemah. Oleh sebab itu pemerintah harus berfikir keras bagaimana mengantisipasi meluasnya penyebaran virus itu, termasuk di wilayah Kec.Lambuya Provinsi Sulawesi Tenggara.

Keadaan perekonomian indonesia saat ini sangatlah buruk. Dikutip dari CNN Indonesia,menteri keuangan Republik Indonesia mengatakan bahwa proyeksi pertumbuhan ekonomi indonesia hanya akan mencapai 2,3\%. Bahkan, dapat saja dalam kondisi terburuk,ekonomi indonesia mencapai minus hingga 0,4\%. Penyebab dari penurunan ekonomi ini adalah karena turunnya konsumsi dan investasi,baik dalam lingkup rumah tangga maupun pemerintah sendiri. Dengan adanya kejadian pandemi COVID -19 secara global ini minat beli kebutuhan ikut menurun, karena masyarakat dihimbau oleh pemerintah untuk melakukan sosial distancing demi memutus rantai penyebaran virus covid-19.Akibat dari pandemi covid-19 ini juga berdampak pada turunnya permintaan terhadap produk-produk bahan pokok . Kelas ekonomi menengah berpotensi besar menjadi kelas ekonomi bawah karena mata pencaharian mereka terganggu pada masa pandemi ini. Masyarakat menengah ke bawah juga banyak yang mengalami kerugian apalagi masyarakat yang berjualan baik dirumah ataupun di pasar-pasar akibat virus covid ini.

\section{LANDASAN TEORI}

Berkaitan dengan adanya WorkFrom Home atau WFH dan social distancing membuat gerak masyarakat dalam kehidupan menjadi tersendat karena pada Work From Home atau WFH masyarakat tidak bisa keluar rumah dan dengan social distancing masyarakat dilarang keras untuk berkegiatan yang sifatnya berkumpul atau berkelompok. Padahal mereka harus tetap memenuhi kebutuhan hidupnya. Hal ini memengaruhi kehidupan masyarakat termasuk sektor ekonomi. Banyak toko dan tempat jual beli yang ditutup sehingga masyarakat menjadi sulit untuk memenuhi kebutuhan hidupnya. Larangan untuk keluar rumah membuat ruang gerak masyarakat menjadi lebih sempit. Padahal justru saat seperti ini kebutuhan hidup semakin bertambah sehingga mempengaruhi niat beli masyarakat.Melihat situasi tersebut maka terlihat bahwa teori pemasaran yang dilandasi oleh bauran pemasaran yang dikemukakan oleh Kotler (2000), kini mengalami pergeseran. Konsumen dalam hal ini masyarakat lebih mementingkan untuk pemenuhan kebutuhan pokok yang dapat menunjang untuk bertahan hidup. Situasi telah mengubah persepsi masyarakat ke dalam tingkat psikologis yang baru dalam menentukan keputusannya untuk melakukan pembelian terhadap barang-barang kebutuhan pokok. Dalam situasi yang normal, produk, harga dan tempat mampu berpengaruh langsung terhadap keputusan membeli, namun dalam kondisi darurat, maka akan menimbulkan hasil yang lain.

Kotler dan Armstrong, (2010: 200) mengungkapkan perilaku konsumen dapat dipengaruhi oleh beberapa faktor, diantaranya ;Pertama, Faktor Kebudayaan meliputi ; 1) Budaya merupakan faktor penentu keinginan dan perilaku seseorang yang paling mendasar. Pemasar selalu berusaha mengenali pergeseran budaya untuk menemukan produk baru yang diinginkan. 2) Sub-Budaya merupakan identifikasi dan 
Muhammad Pariama dan Takwim, Dampak Pandemi Covid-19 terhadap Minat Beli Masyarakat di Kecamatan Lambuya Kabupaten Konawe Provinsi Sulawesi Tenggara

sosialisasi yang khas untuk perilaku anggotanya. Dapat dibedakan adanya empat macam sub-budaya, yaitu: kelompok kebangsaan, kelompok keagamaan, kelompok ras dan daerah geografis. 3) Kelas Sosial, merupakan sebuahkelompok yang relatif sejenis dan bertahan dalam sebuah masyarakat, yang tersusun dalam sebuah urutan jenjang, dan para anggota dalam setiap jenjang memiliki nilai, minat dan tingkah laku yang sama. Kedua, Faktor Sosial yang meliputi ; 1) Kelompok, Sikap dan perilaku individudipengaruhi oleh banyak kelompok kecil. Kelompok yang berpengaruh langsung terhadap individu disebut kelompok keanggotaan. Kelompok referensi, tampil sebagai pengacuan langsung atau tidak langsung dalam membentuk sikap dan perilaku seseorang. Kelompok aspirasional di nama mereka tidak termasuk anggota akan tetapi mempunyai keinginan untuk berpartisipasi / mengikuti. Kelompok biasanya mempunyai pemimpin opini yaitu orang dalam kelompok referensi yang karena keterampilan, pengetahuan, kepribadian, atau karakteristik khusus lainnya mempunyai pengaruh terhadap anggota yang lain. 2) Keluarga, Anggota keluarga sangat mempengaruhi perilaku pembeli. Keluarga masih merupakan organisasi pembelian konsumen terpenting dalam masyarakat. 3) Peran dan Status, Masing-masing peran membawa status yang mencerminkan penghargaan umum yang diberikan kepada peran oleh masyarakat. Peran dan status bukan merupakan variabel yang konstan. Banyak profesional pemasaran dan penjualan membuat kekeliruan penilaian yang terkait dengan peran dan status calon pelanggan. Ketiga, Faktor Pribadi meliputi; 1) Usia dan Tahap Daur Hidup, Jenis barang dan jasayang dibeli oleh konsumen berubah seiring dengan bertambahnya usia. Pemasar kerap mendefinisikan pasar sasarannya berdasarkan siklus/daur hidup, dan mengembangkan produk serta rencana pemasaran yang cocok. 2) Pekerjaan, Pekerjaan mempengaruhi barang dan jasa yang dibeli seseorang / konsumen. Pemasar berusaha mengidentifikasi kelompok pekerjaan yang memiliki minat di atas rata-rata terhadap produk dan jasa. Bahkan pembuatan spesialisasi pembuatan produk untuk pekerjaan tertentu. 3) Situasi Ekonomi, Pemasar perlu mengamati kecenderungan yang menyangkut pendapatan pribadi, tabungan, dan tingkat bunga. Bila indikator ekonomi menunjukkan adanya resesi, mereka dapat mendesain dan memposisi ulang, serta mengubah harga produk mereka. 4) Gaya Hidup, Dimensi orientasi diri membuat tiga macam pendekatan membeli terhadap pembeli, yaitu :berorientasi pada prinsip, yang membeli berdasarkan pandangan mengenai bagaimanakeadaan yang seharusnya; berorientasi pada status, yang mendasarkan pembelian pada tindakan dan opini orang lain; dan berorientasi pada tindakan, yang digerakkan oleh keinginan akan aktivitas, variasi, dan resiko. 5) Kepribadian dan Konsep Diri, merupakan karakteristik psikologis pembeda diri yang memperlihatkan tanggapan yang relatif bersifat individual, konsisten, dan abadi terhadap lingkungannya. Kepribadian dapat bermanfaat saat menganalisis perilaku konsumen terhadap beberapa pilihan produk dan merek. Keempat, Faktor Psikologis, meliputi ; 1) Motivasi, merupakan kebutuhan yangmendorong seseorang untuk mencari kepuasan atau kebutuhan. 2) Persepsi, merupakan setiap tindakan seseorang yang termotivasi akan dipengaruhi oleh persepsinya terhadap situasi tertentu. Persepsi adalah proses menyeleksi, mengorganisasi/mengatur, dan menginterpretasikan masukan-masukan informasi. 3) Pembelajaran, meliputi perubahan perilaku seseorang yang timbul dari pengalaman. Para ahli teori pembelajaran yakin bahwa pembelajaran dihasilkan melalui perpaduan kerja antara dorongan, rangsangan, petunjuk bertindak, tanggapan, dan penguatan. 4) Keyakinan dan Sikap, Keyakinan dapat membentuk citra produk dan merek, dan konsumen akan bertindak berdasarkan citra tersebut.

Menurut Ir Laeli Sugiyono MSi Statistisi Ahli Madya pada BPS Provinsi Jawa Tengah (2020) tak bisa dielakkan hempasan badai pandemi COVID-19 telah meluluhlantakan sendi-sendi sosial ekonomi masyarakat, hampir semua negara merasakan terpaan dahsyatnya gelombang panas pandemi ini. Penyebaran COVID-19 makin tak terbendung alih-alih memulihkan ekonomi untuk menggerakan perekonomian yang diambang resesi. Pandemi COVID-19 yang melanda sontak merubah pola pengeluaran warga yang tak terduga, apa saja fakta dan data yang menyangkut perubahan tersebut? Yang dialami warga Jawa Tengah tiba-tiba merasa pengeluarannya meningkat dan atau menurun selama pandemi COVID-19.Tercatat 56,1\% responden mengalami peningkatan pengeluaran, 16,3\% mengalami penurunan pengeluaran, dan sisanya tetap di masa pandemi Covid-19 bila dibandingkan kondisi sebelum wabah. Diantara 44,30\% responden yang mengalami peningkatan pengeluaran, besarnya mencapai $26 \%$ hingga $50 \%$ dibanding sebelum wabah. 
Muhammad Pariama dan Takwim, Dampak Pandemi Covid-19 terhadap Minat Beli Masyarakat di Kecamatan Lambuya Kabupaten Konawe Provinsi Sulawesi Tenggara

Sebaliknya diantara $37,20 \%$ yang mengalami penurunan pengeluaran, besarnya mencapai $26 \%$ hingga $50 \%$ dibanding sebelum wabah.

\section{METODE}

\section{Diagram Alur Penelitian}

Penelitianpadatahunpertamadiarahkan pada identifikasidananalisisDampak Pandemi Covid 19 terhadap minat beli masyarakat di kec.Lambuya Kab.Konawe,sertadesain/modelDampak Pandemi Covid 19 terhadap minat beli masyarakat di kec.Lambuya Kab.Konawe melalui metode literatur atau kepustakaan (library research). Adapun pendekatan yang diterapkan yakni pendekatan analisis deskriptif terhadap datadata literer yang berkaitan dengan masalah yang diteliti. Sumber data penelitian terdiri atas sumber data primer dan sumber data sekunder.

\section{Lokasi, Obyek dan unit analisis Penelitian}

Penelitian ini dilaksanakan pada beberapa toko tempat berbelanja di sekitar Kec.Lambuya. Dan untuk membatasi lingkup penelitian telah ditetapkan dilaksanakan pada beberapa toko tempat berbelanja di sekitar Kec.Lambuya. Pemilihan toko yang berbeda tersebut merupakan tokoyang menyediakan kebutuhan masyarakat sehari-hari. Sehubungan hal tersebut,informan yang dipilih dalam penelitian ini (melalui metode wawancara) adalah :1) Pemilik Toko, 2) Warga Masyarakat Kec. Lambuya.

\section{Teknik Pengumpulan Data}

Menurut Sugiyono (2013:224) teknik pengumpulan data merupakan langkah yang paling strategis dalam penelitian, karena tujuan utama dari penelitian adalah mendapatkan data. Berikut teknik pengumpulan data:

\section{a. Teknik Wawancara}

Menurut Esterberg dalam Sugiyono (2013:231) wawancara merupakan pertemuan dua orang untuk bertukar informasi dan ide melalui tanya jawab, sehingga dapat dikontruksikan makna dalam suatu topik tertentu.

\section{b. Teknik Pengamatan/Observasi}

Sutrisno Hadi dalam Sugiyono (2013:145) mengemukakan bahwa, observasi merupakan suatu proses yang kompleks, suatu proses yang tersusun dari berbagai proses biologis dan psikhologis. Dua diantara yang terpenting adalah proses-proses pengamatan dan ingatan.

\section{c. Teknik Dokumentasi}

Menurut Sugiyono (2013:240) dokumen merupakan catatan peristiwa yang sudah berlalu. Dokumen bias berbentuk tulisan, gambar, atau karya-karya monumental dari seorang. Dokumen yang berbentuk tulisan misalnya catatan harian, sejarah kehidupan(life histories)

d. Triangulasi

Dalam teknik pengumpulan data, triangulasi diartikan sebagai teknik pengumpulan data yang bersifat menggabungkan dari berbagai teknik pengumpulan data dan sumber data yang telah ada.

\section{Analisis Data}

Menurut Cooper (2006) dalam menentukan ukuran sampel untuk populasi yang tidak terdefinisikan secara pasti, jumlah sampelnya dapat ditentukan secara langsung sebesar 100. Dalam penelitian ini jumlah sampel yang dipakai 150 responden. Untuk menganalisis data hasil survey, menginterpretasi hasil penelitian maka digunakan teknik analisis regresi linearberganda, untuk mengetahui seberapa besar pengaruh antara perubahan perilaku konsumen danperubahan pola pengeluaran terhadap minat beli masyarakat. Teknik pengumpulan data dilakukan melalui kuesioner. Skala pengukuran menggunakan skala Likert. Sumber data yang digunakan yaitu data primer yakni data yang diperoleh secara langsung melalui kuesioner dan data sekunder yang diperoleh dalam bentuk dokumen-dokumen. 
Muhammad Pariama dan Takwim, Dampak Pandemi Covid-19 terhadap Minat Beli Masyarakat di Kecamatan Lambuya Kabupaten Konawe Provinsi Sulawesi Tenggara

\section{HASIL DAN PEMBAHASAN}

Dampak Pandemi Covid-19 terhadap Minat Beli Masyarakat di Kecamatan Lambuyadalam hal ini himbauan yang diterapkan pemerintah berupa stay at home, work from home, study from home sebagai bentuk antisipasi penyebaran covid-19 telah begitu besar mempengaruhi semua bidang kehidupan. Covid-19 yang begitu cepat merebak menyebabkan kebiasaan masyarakat banyak berubah, mulai dari bidang kesehatan, teknologi, bahkan ekonomi telah menyebabkan kebiasaan baru dalam masyarakat yang dikenal dengan istilah "The New Normal". The new normal sendiri bisanya digunakan dalam ekonomi dan bisnis yang mengacu pada kondisi keuangan setelah krisis keuangan 2007-2008 dan setelah resesi global 2008-2012. Namun semenjak itu digunakan dalam berbagai konteks lain untuk menunjukkan bahwa sesuatu yang sebelumnya tidak normal dianggap menjadi biasa.

Pengujian validitas dan reliabilitas juga dilakukan untuk menguji instrumen yang digunakan. Hasil pengujian validitas dan reliabilitas ditunjukkan pada tabel 2 dan 3 sebagai berikut :

Tabel 1. Hasil Uji KMO dan Bartlett of Sphericity

\begin{tabular}{cc}
\hline Uji & Nilai \\
Sample Adequacy KMO & 0.815 \\
Bartlett of Sphericity & 0.000 \\
\hline Sumber : Hasil Olah Data Tahun 2021
\end{tabular}

Dari hasil pengujian KMO and Bartlett Test of Sphericity dapat dilihat bahwa nilai Sample Adequacy KMO sebesar 0,815 yang berarti nilai pengujian instrumen baik. Sedangkan nilai Bartlett of Spherecity sebesar 0,000 yang berarti signifikan. Maka dapat dikatakan hasil pengujian validitas instrumen dalam penelitian ini valid.

Tabel 2. Hasil Uji Convergent Validity dan Reliability

\begin{tabular}{lc}
\hline \multicolumn{1}{c}{ Item } & Loading \\
Pola Perilaku Konsumen $(\mathrm{CR}=0.787)$ & \\
PK1 & $\mathbf{0 . 8 2 0}$ \\
PK2 & $\mathbf{0 . 7 9 6}$ \\
PK3 & $\mathbf{0 . 7 8 8}$ \\
PK4 & $\mathbf{0 . 7 7 3}$ \\
PK5 & $\mathbf{0 . 7 8 0}$ \\
PK6 & $\mathbf{0 . 7 7 2}$ \\
PK7 & $\mathbf{0 . 7 6 9}$ \\
Perubahan Pola Pengeluaran $(\mathrm{CR}=0.787)$ & \\
PP1 & $\mathbf{0 . 7 7 0}$ \\
PP2 & $\mathbf{0 . 7 7 5}$ \\
PP3 & $\mathbf{0 . 7 6 9}$ \\
Minat Beli $(\mathrm{CR}=0.822)$ & \\
MB1 & $\mathbf{0 . 7 7 7}$ \\
MB2 & $\mathbf{0 . 7 7 7}$ \\
MB3 & $\mathbf{0 . 8 5 4}$ \\
MB4 & $\mathbf{0 . 7 6 6}$ \\
MB5 & $\mathbf{0 . 7 7 3}$ \\
MB6 & $\mathbf{0 . 8 0 6}$ \\
\hline
\end{tabular}

Sumber : Hasil Olah Data Tahun 2021

Tabel 2 menunjukkan bahwa nilai reliabilitas instrumen dalam penelitian ini baik. Cronbach alpha variabel nilai harga sebesar 0.787, variabel Pola Perilaku Konsumen sebesar 0.787, dan variabel minat beli sebesar 0.822. Dari nilai cronbach alpha setiap instrumen juga lebih dari 0.7, maka dapat disimpulkan bahwa intrumen yang digunakan dalam penelitian ini reliabel.Pengujian yang digunakan dalam penelitian ini adalah 
uji regresi linier berganda. Pengujian ini bertujuan untuk mengukur seberapa pengaruh variabel independen terhadap variabel dependen. Pengujian dilakukan dengan bantuan software SPSS.

Berdasarkan hasil pengujian hipotesis pertama, didapatkan nilai thitung sebesar 1.657, yang nilainya lebih kecil jika dibandingkan dengan ttabel yaitu sebesar 1.970.Dari nilai thitung dapat dinyatakan bahwa pola perilaku konsumen tidak berpengaruh terhadap minat beli masyarakat saat pandemi karena thitung 0.05 yang berarti pola perilaku konsumen tidak mempengaruhi minat beli masyarakat saat pandemi.

Berdasarkan hasil pengujian hipotesis kedua, didapatkan nilai thitung sebesar 5.154, yang nilainya lebih besar jika dibandingkan dengan ttabel yaitu sebesar 1.970. Dari nilai thitung dapat dinyatakan bahwa perubahan pola pengeluaran berpengaruh positif terhadap minat beli masyarakat saat pandemi karena thitung $>$ ttabel. Berdasarkan pengujian secara parsial dalam penelitian ini perubahan pola pengeluaran terbukti berpengaruh positif dan signifikan terhadap minat beli. Hal ini ditunjukkan oleh nilai signifikansi 0.000 . Nilai signifikansi yang diperoleh $0.000<0.05$ yang berarti perubahan pola pengeluaran mempengaruhi minat beli masyarakat saat pandemic covid 19.

Berdasarkan hasil pengujian secara simultan pada hipotesis ketiga, didapatkan nilai R sebesar 0.405 , R Square 0.164, dan nilai Adjusted R Square sebesar 0.157. Dari nilai R Square dapat diinterpretasikan bahwa 16,4\% variabel minat beli dipengaruhi oleh variabel Pola Perilaku konsumen dan perubahan pola pengeluaran. Dengan kata lain, sebanyak $83,6 \%$ minat beli masyarkat dipengaruhi oleh variabel selain pola perilaku konsumen dan perubahan pola pengeluaran, seperti produk, promosi, dan sebagainya. Hasil ini menunjukkan pengaruh Pola Perilaku konsumen dan perubahan pola pengeluaran terhadap minat beli masyarkat dalam kategori lemah. Meskipun lemah, secara simultan Pola Perilaku konsumen dan perubahan pola pengeluaran berpengaruh positif dan signifikan terhadap minat beli Masyarkat saat pandemi. Hal ini ditunjukkan oleh hasil uji bahwa nilai uji $\mathrm{F}$ sebesar 22.683 dan signifikan pada 0.000 . Nilai uji Fhitung $>$ Ftabel yaitu 22.683 $>2.326$ yang berarti jika Pola Perilaku konsumen dan perubahan pola pengeluaran masyarkat semakin baik maka minat beli masyarakat semakin meningkat.

Salah satu variabel yang diprediksikan mampu mempengaruhi minat beli adalah perilaku konsumen. Namun berbeda dengan hasil penelitian ini, yang membuktikan bahwa perilaku konsumen tidak mampu mempengaruhi minat beli masyarakat saat pandemi. Perilaku konsumen tidak berpengaruh terhadap minat beli masyarkat. Masyarkat cenderung lebih selektif dalam memilih barang yang akan dibelinya. Masyarakat memilih mengorbankan uangnya untuk membeli produk yang berkualitas dan awet. Hasil penelitian ini menolak penelitian sebelumnya yang menyatakan bahwa perilaku berpengaruh terhadap minat beli pelanggan (Nurulhanifah, 2020). Variabel lain yang memiliki pengaruh terhadap minat beli adalah perubahan pola engeluaran. Penelitian ini membuktikan bahwa perubahan pola pengeluaran memiliki pengaruh positif dan signifikan terhadap minat beli Masyarakat saat pandemi.

\section{SIMPULAN}

Terjadinya pandemi COVID-19 dan sehingga diberlakukannya PSBB oleh pemerintah membawa fenomena yang baru di dalam hal minat masyarkat untuk melakukan pembelian terhadap barang kebutuhan pookok yang sangat jauh berbeda dari sebelumnya. Dari hasil penelitian ini, dapat disimpulkan bahwa minat beli masyarakat saat wabah COVID-19 tidak dipengaruhi oleh perilaku konsumen tetapi dipengaruhi oleh perubahan pola pengeluaran masyarakat. Hasil ini menunjukkan bahwa upaya untuk meningkatkan minat beli masyarkat dapat dilakukan dengan cara mengubahPola pengeluaran masyarkat terlebih dahulu. Market harus lebih fokus pada perubahan perilaku pengeluaran karena efek perubahan perilaku pengeluaran lebih kuat daripada efek perubahan perilaku konsumen. Sebagai langkah kedepan, maka dengan adanya situasi PSBB sebagai langkah pencegah pandemik COVID-19 yang belum diketemukan vaksinya, maka telah terbentuk wajah market yang baru dengan intervensi psikologis konsumen yang baru secara dominan, di mana perubahan perilaku pengeluaran agar dapat lebih diutamakan dalam waktu yang panjang serta dengan dukungan persediaan barang yang memadai untuk jangka waktu yang panjang pula. Sehingga kelangkaan 
Muhammad Pariama dan Takwim, Dampak Pandemi Covid-19 terhadap Minat Beli Masyarakat di Kecamatan Lambuya Kabupaten Konawe Provinsi Sulawesi Tenggara

yang akan berdampak terhadap perubahan perilaku pengeluaran dapat teratasi dengan baik dan masyarakat tidak terlalu terbebani untuk mendapatkannya dalam situasi tanggap darurat.

\section{DAFTAR PUSTAKA}

Ali Hasan. (2014), Marketing dan Kasus-Kasus Pilihan, CAPS, Yogyakarta.

Hidayat, A. T., Elita, F. M. and Setiaman, A. (2012) 'Hubungan Antara Atribut Produk Dengan Minat Beli Konsumen', Students e-Journal.

Kotler. P. 2011. Manajemen Pemasaran. Jilid 2. Bumi Aksara. Jakarta.

Kotler, P. (2012) 'Marketing management/Philip Kotler, Kevin Lane Keller', Pearson Education International.

Saifudin, S. 2019. Pengaruh Iklan Islami Terhadap Minat Beli Calon Konsumen Matahari Dept. Store di Jawa Tengah, Jurnal Bisnis dan Manajemen Islam, 7 (2), 143-160.

Setiadi Nugroho J,(2011),Perilaku Konsumen: Konsep dan Implikasi untuk Strategi dan Penelitian Pemasaran, Prenada Media, Bandung.

Schiffman, L. and Kanuk, L. L. (2008) 'Perilaku konsumen', Jakarta: Indek

Hutauruk, M. R., Ghozali, I., Sutarmo, Y., Mushofa, A., Suyanto, Astri Yulidar, M., et al. (2019) 'Aplication of marketing mix: Study on two-wheeled vehicle users in deciding to buy fuel on roadside unofficial kiosks (at samarinda Indonesia)', International Journal of Scientific and Technology Research, 8(12), pp. 1275-1279.

Khan, J. H., Haque, A. and Rahman, M. S. (2013) 'What makes tourists satisfied? An empirical study on malaysian islamic tourist destination', Middle East Journal of Scientific Research. doi: 10.5829/idosi.mejsr.2013.14.12.2250. 